\title{
Protection in Life and Death: Pendant Crosses from the Cemetery of Apollo Klarios at Sagalassos, Turkey
}

\author{
Sam Cleymans and Peter Talloen \\ Sagalassos Archaeological Research Project, University of Leuven, Belgium
}

This article presents the different types of pendant crosses found in the burials of a Middle Byzantine graveyard at the Pisidian settlement of Sagalassos in south-western Turkey. The aim is to study both the chronology and function of these pectoral crosses. A variety of sources are used, ranging from stratigraphy and radiocarbon dates to contextual information and skeletal data. The crosses could be broadly dated to between the eleventh and thirteenth century $A D$, thus providing an indication of the lifespan of the cemetery. Moreover, the typological evolution, which was corroborated by parallels from other sites in the Byzantine Empire, allowed us to establish a horizontal stratigraphy for the graveyard. The pectoral crosses discussed here shed light on the funerary practices in this part of the Byzantine world. These generally proved to belong to very young children. They constitute a category of material culture that not only provides insights into the lives of the Byzantine population, especially in early childhood, but are also the material manifestation of the intersection between popular religion, magic, and funerary rites.

Keywords: pectoral cross, Sagalassos, Middle Byzantine, funerary practices, children

\section{INTRODUCTION}

In 1994, a cemetery was discovered on the western slope of the Lower Agora of Sagalassos (Waelkens et al., 1997: 20514), a city in the ancient region of Pisidia (south-western Anatolia). Further excavations, through to 2008, revealed that this graveyard extended to the east and south of the former temple of Apollo Klarios, situated on the hill overlooking the Lower Agora to the east (Waelkens et al., 2000: 362-84; Ricaut \& Waelkens, 2008: 53564). This Ionic peripteral temple, dating to the last decades of the first century BC, was converted into a tripartite transept basilica in the late fifth to early sixth century AD (Talloen \& Vercauteren, 2011: 368-70). The Christian basilica was damaged in a seventh-century earthquake and possibly abandoned for some time, as were other parts of the former city, when the nucleus of the settlement shifted to the south. There, the temenos of the former sanctuary of the imperial cult became the centre of a new fortified settlement or kastron (Poblome et al., 2017). By at least the eleventh century, the religious function of the Apollo Klarios site was restored, when a smaller structure, possibly a chapel, was built within the shell of the former basilica. This date is given by several anonymous eleventh-century folles (Byzantine bronze coins) which were retrieved from the floor level of tamped earth and its substrate inside the transept of the former church (Talloen, 2007: 32730) (Figure 1). 


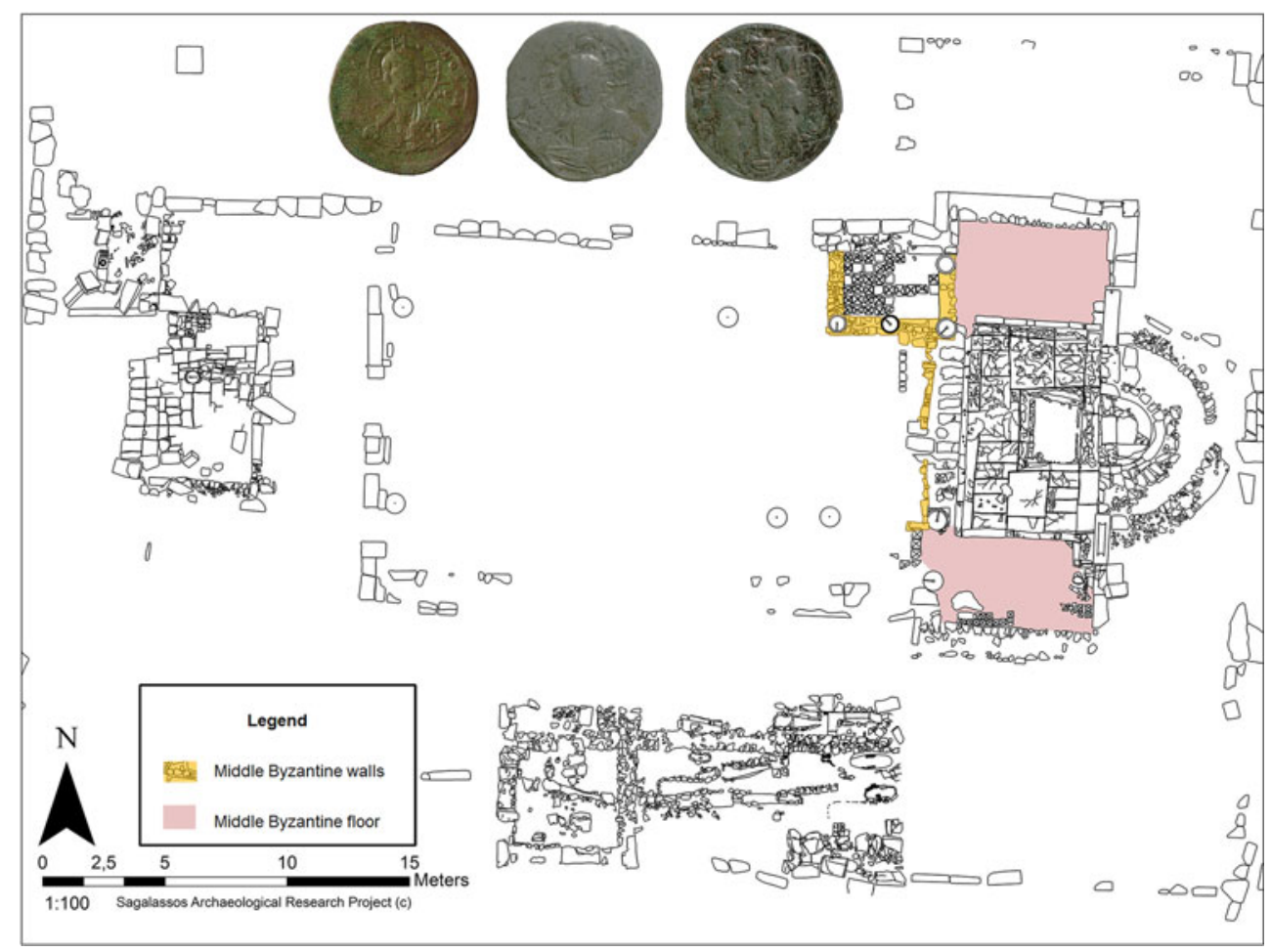

Figure 1. Plan of the eleventh-century phase of the funerary chapel, showing the Middle Byzantine walls and floor levels, as well as three of the folles found in the walking level substrate.

It was at this time that the graveyard was established at the site. A total of seventy-nine skeletons in fifty-eight burials have so far been excavated over the course of several campaigns. Originally, the individuals were interpreted as victims of an epidemic or of the earthquake that devastated Sagalassos in the seventh century $\mathrm{AD}$ on the basis of their presence among the debris caused by this seismic event (Waelkens et al., 1997: 212, 2000: 377). The study of the glass objects found in some of the burials (Lauwers, 2008: 21314), however, suggested a Middle Byzantine date for the graveyard, more specifically between the tenth and thirteenth centuries AD. This was later corroborated by radiocarbon dating on six of the skeletons (Ricaut \& Waelkens, 2008: 540). More recently, in 2016, three more skeletons were successfully radiocarbondated, providing dates between the eleventh and thirteenth centuries and, thus, confirming the proposed timeframe (Figure 2).

None of the burials was located inside of the former church; they were arranged around it to the south and east, all the way down to the Lower Agora and the socalled Agora Gate on the south side of the square, the remains of both of which had largely been covered by (earthquake) debris. Northward and westward extensions of the graveyard are not attested so far as these areas have not yet been excavated, but they can be expected. The graveyard thus seemingly respected the Middle Byzantine phase of the church, although the latter has also not been completely fully excavated and burials may be 


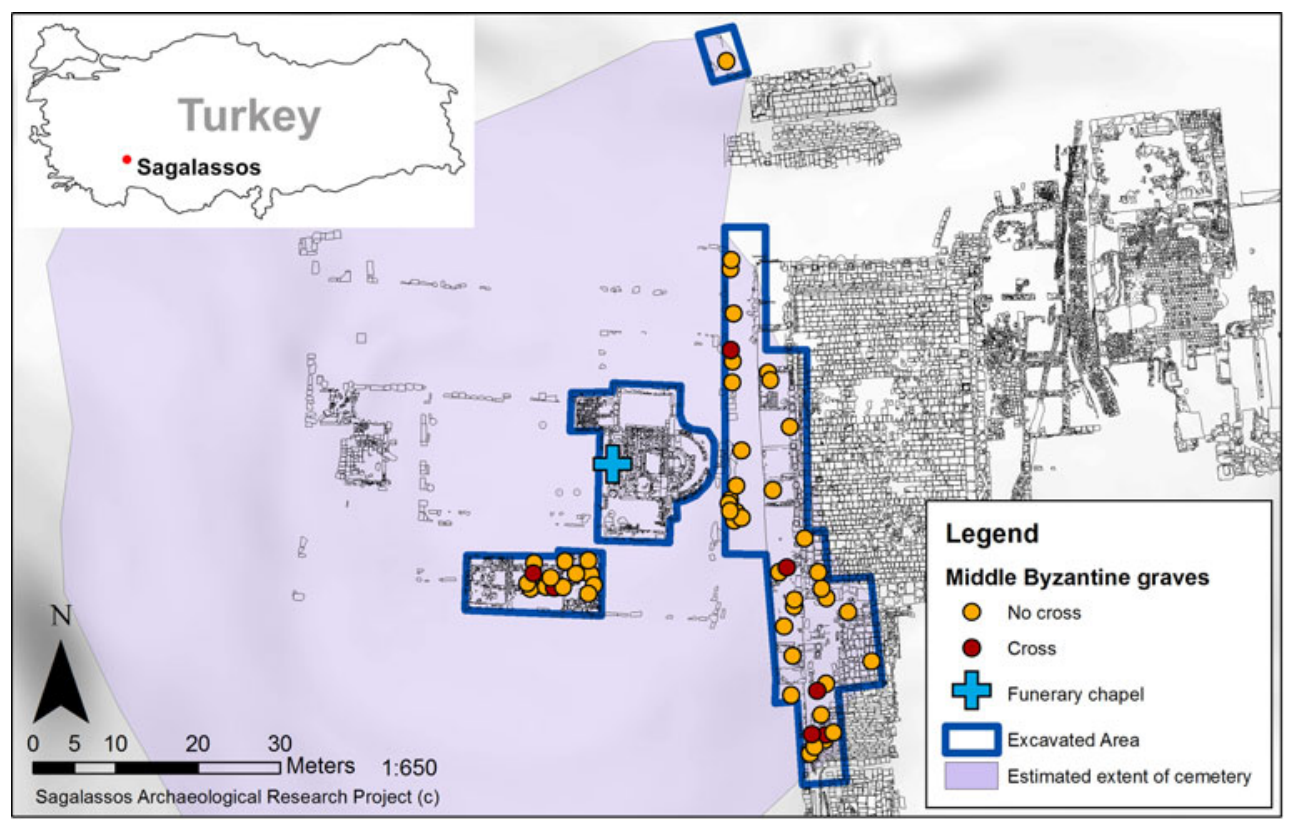

Figure 2. Plan of the graveyard around the converted temple of Apollo Klarios showing the presence of pectoral crosses.

present in the area of the narthex, as was the case in the lower city church of Amorium in the tenth-eleventh centuries (Ivison, 2010: 335-38). The study of the ceramics in the deposits in which the burials were arranged indicates that the walking level over the architectural debris, formed by the collapse of the western portico of the Lower Agora during the seventh century, was raised and levelled by the deposition of large amounts of earth during the subsequent centuries. In this way, a process of landscaping appears to have been carried out, partly in order to facilitate the layout of the graveyard (Cleymans \& Poblome, forthcoming).

Generally, little variation in burial shape and content was observed. They were simple, shallow, roughly rectangular, or trapezoidal pits dug into the ground, which consists of an ophiolitic mix on the hill, and of debris and loose earth on the western slope of the Lower Agora and the Agora Gate (Figure 3). These pits were often lined with stone rubble, tile, or spolia, and sometimes covered with slabs or tiles. The deceased were placed into these pits, either individually or as multiple inhumations, some of the latter being secondary interments. The bodies of the deceased were oriented east-west, which was typical for Christian burial in Asia Minor as observed at other Dark Age and Middle Byzantine sites (Ivison, 1993: 7-8 and note 12). Their heads were at the west end of the grave so that upon rising they would be facing east, the direction from which Christ would appear at the time of his Second Coming (Matthew 24: 27). All the dead were interred in supine position, mostly with arms folded over the chest or abdomen. Only in two graves were the heads of the deceased propped up. They were probably placed directly in the pit and not laid to rest in wooden coffins as almost no nails were found. Nevertheless, the 


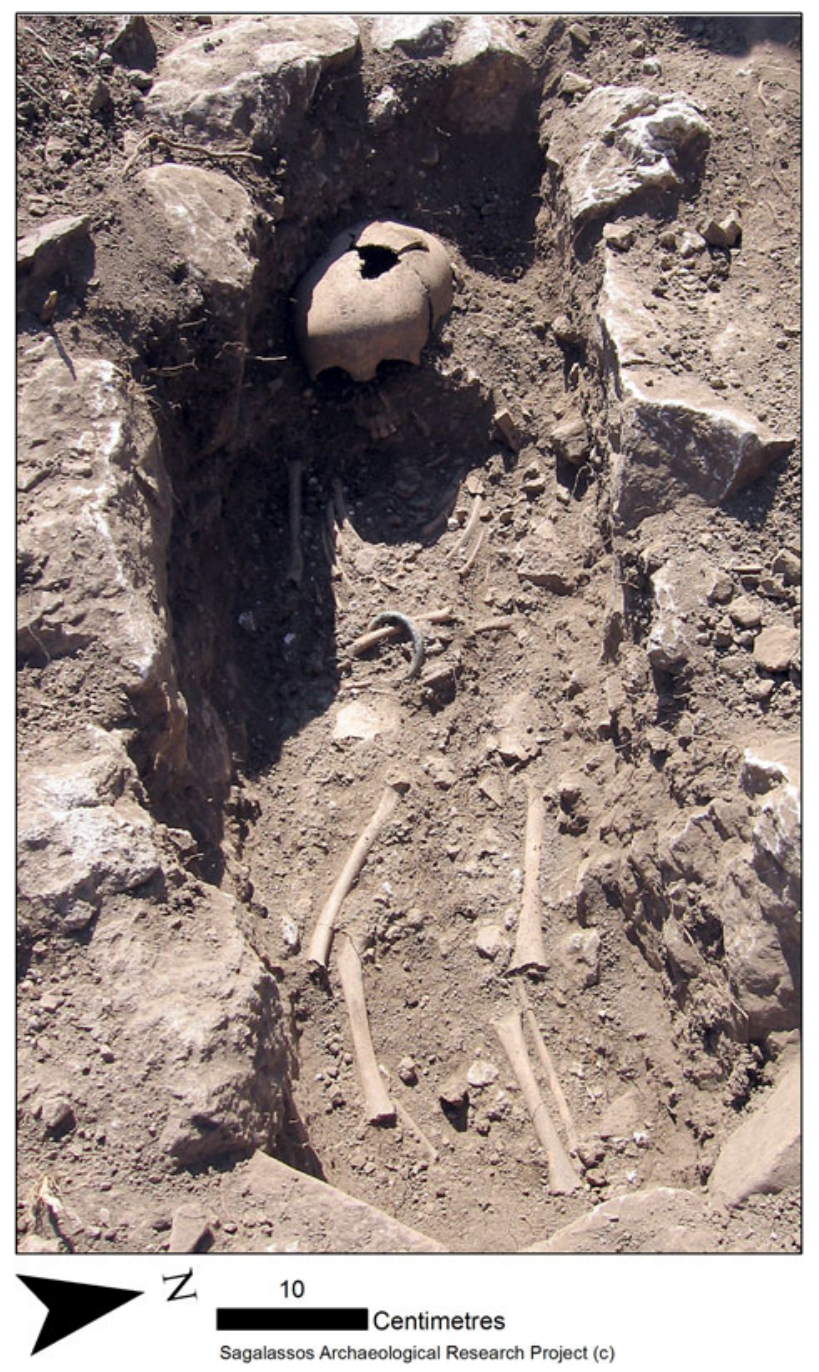

Figure 3. View of burial no. 2 of 2005, south of the church.

position of the foot bones of some wellpreserved adult individuals indicated that they fell apart during decomposition. This is only possible if the remains were located in a cavity. The shape of some of the burial pits and the location of four nails in one grave suggest that the graves which were not covered with tiles or limestone slabs were possibly protected by a wooden cover. No grave markers have been found.
Of the group of seventy-four individuals studied, forty-six (62 per cent) were subadults, below eighteen years of age. In thirty-two cases (55 per cent of all graves), the graves contained only sub-adult individuals; seventeen (or 29 per cent) included only the remains of adults, and nine (or 16 per cent) those of sub-adults and adults together. The mixed distribution of adult and sub-adult graves around the church demonstrates that no special area was 


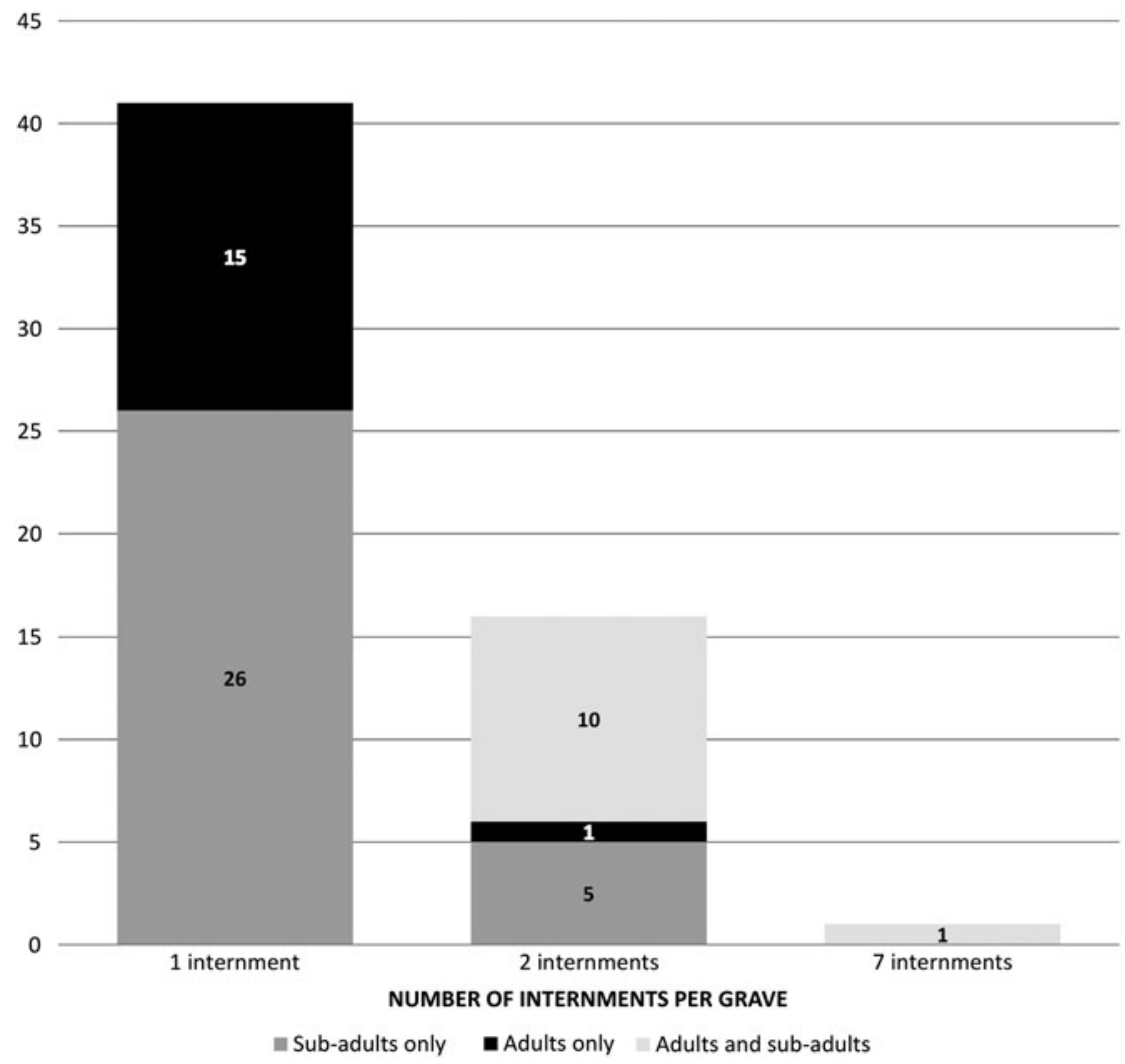

Figure 4. Graph showing the number of individuals buried per grave.

reserved for the burial of sub-adults (Figure 4).

Grave goods or funerary offerings placed in the graves during the burial ceremony, such as small ceramic pitchers and glass perfume flasks, which were common in late antique burials at Sagalassos (Talloen \& Poblome, 2014: 250-51), were no longer present. The absence of elements of clothing, like buttons, buckles, brooches or pins, suggests that the individuals were not buried wearing their normal garments but stripped of their clothing and dressed in funerary garments, which conforms to the standard burial practice of this period (Davies, 1999: 199; Moore, 2013: 112). On the other hand, personal ornaments, such as earrings, finger rings, glass bracelets, and necklaces with pendants, were found, which the deceased were either allowed to keep or given as grave goods. Only thirteen graves (22 per cent) contained such personal ornaments, a relatively low proportion, as also suggested by Sophie Moore's study of Byzantine burial practices in Asia Minor (Moore, 2013: 140).

In several burials, these personal ornaments included cross-shaped pendants. Pendant crosses were a common feature in Byzantine burials; but, in spite of their popularity, studies devoted to them are few. Like hollow reliquary crosses, flat cross-shaped pendants are designated as enkolpia (Schoolman, 2010: 375): while the former were objects of devotion containing a relic of a saint or a fragment of 
the True Cross, the latter were apotropaic amulets used to protect those who wore them. Reliquary crosses have recently been studied (Pitarakis, 2006), but the different types of pectoral crosses are rarely welldefined (for an exceptional study of crosses from Crimea, see Khairedinova, 2012). They are even less well dated, with stylistic criteria generally serving as the basis (Schoolman, 2010: 377). Together with other items found in burials, such as glass bracelets, copper-alloy earrings, and finger rings, the significance of these items of jewellery lie in the closed archaeological context in which they were found, as they were arranged ad personam. Consequently, they can inform us about the religious beliefs and the social practices of the deceased and the families that were burying them. Yet hardly any attention is ever paid to their archaeological context. Moreover, their interpretation is usually limited to being protective devices that accompanied their owners to the grave, while fundamental insight into the age and gender of the individuals that wore them is missing (e.g. Schoolman, 2010). This is, to a large extent, the result of the state of research concerning Byzantine funerary practices. Although there are several studies on death and dying in the Byzantine period (e.g. Talbot, 2009; Constas, 2010), much of this relies on literary sources. The latter generally concern the ruling elite, saints, or clergymen, who were concentrated in the imperial capital, thus creating uneven coverage regarding social class, gender, and geographical region. Only recently have archaeological studies started to shed more light on Middle Byzantine burial practices in Asia Minor (e.g. Moore, 2013).

The aim of this article is to define the different types and chronology of cross pendants found at Sagalassos, as well as to characterize their use by looking at the age and gender of people who made use of them. In the case of Sagalassos, the 58 burials from the Apollo Klarios graveyard yielded a total of eleven pectoral crosses representing several types, which made it possible to establish a typology. Furthermore, elements of absolute radiocarbon dates calibrated with $\mathrm{OxCal} 4.3$ (Bronk Ramsey, 2009), and the atmospheric curve IntCal13 (Reimer et al., 2013) and relative (stratigraphic) chronology are available to ascertain a more accurate timeframe for the different types and uses of such pendants. Finally, studies conducted on the associated human remains allow us to establish the age and gender of their owners.

\section{TyPOLOGY}

The eleven pectoral crosses found in the burials of the Apollo Klarios graveyard represent five main types. Some could be divided into subtypes.

\section{Type 1}

Type 1 consists of forged iron crossshaped pendants.

\section{Type 1a}

This subtype comprises forged iron crossshaped pendants made by bending an iron rod with a rectangular section. This resulted in the two short and two long arms of the cross, on whose upper part a suspension loop was added.

\section{SA-1999-LA-18.3 (Figure 5(k))}

This forged iron cross-shaped pendant (19 mm wide; the top part is badly corroded) was found inside burial no. 2, excavated in 1999 (SA-1999-LA-II: sector 

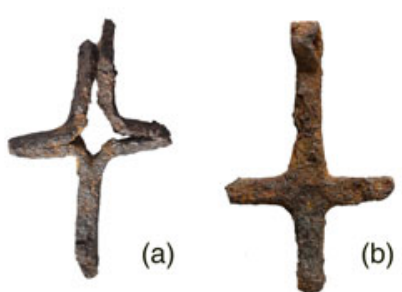

(b)

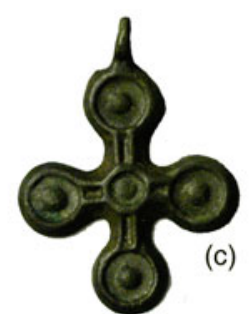

(c)

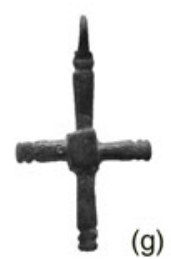

(g)
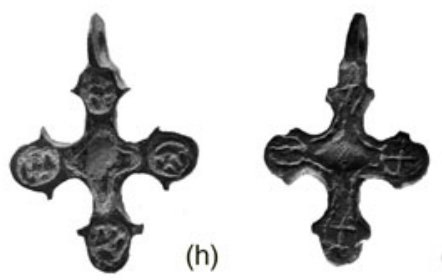

(j)

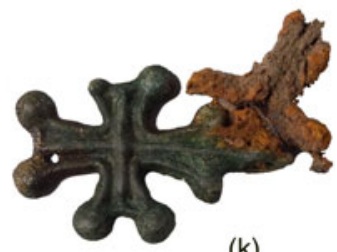

(k)

\section{$1 \mathrm{~cm}$}

Figure 5. Overview of the eleven pectoral crosses found in Middle Byzantine burial contexts.

2390/2315; layer 2), which was located between the eastern temenos wall of the former sanctuary and the western terrace wall of the Lower Agora. Within this grave, two children aged one and a half ( \pm one year) and three ( \pm one year) were buried in an east-west orientation with their heads at the western end of the grave, facing east. The skeletons of both children were disturbed and incomplete. This made it impossible to reconstruct the position of the bodies and to associate the cross with either individual. The stone alignment of the burial pit, measuring $0.45 \times 0.35 \mathrm{~m}$, was only partly preserved due to a later disturbance of the grave. This cross pendant was found together with two copper-alloy crosses of Types $2 \mathrm{a}$ and 5 (see below). The Type $1 \mathrm{a}$ and Type 5 crosses were joined because of corrosion, suggesting that they were placed closely together in the burial, probably originally as part of the same necklace. No other items of adornment were found.

\section{SA-2008-AK2-58-66 (Figure 5(a))}

This forged iron cross-shaped pendant (30 mm long and $19 \mathrm{~mm}$ wide; its suspension loop is no longer present) was found south of the Apollo Klarios chapel, within the former temenos, in burial no. 4 of 2008 (SA-2008-AK2-IV: sector 2290/2365, locus 58). In this grave, the remains of an adolescent (fourteen to eighteen years old) and a child (three to five years old) were found. The adolescent was oriented eastwest, facing east, in a supine position with the legs stretched out and the arms folded over the chest, while the child's bones were mingled with those of the adolescent. The grave ( $2.00 \mathrm{~m}$ long and $0.46 \mathrm{~m}$ wide) was cut out of the ophiolite bedrock and lined with tiles. A tile cover, $0.20 \mathrm{~m}$ above the grave floor, separated this burial from a burial superimposed on it (burial no. 3 of 2008).

A similar iron pectoral cross was found in a burial at the Middle Byzantine 
graveyard in the village of Boğazköy in Galatia, which was allegedly abandoned in the second half of the eleventh century due to the Seljuk invasion of the region (Böhlendorf-Arslan, 2012: 365 fig. 13.19), while at Zeytinli Bahçe (Osrhoene) a comparable pendant was found in a grave dated to the twelfth-thirteenth centuries (Dell'Era, 2012: 404 fig. 12g and 405).

\section{Type 1b}

This subtype takes the shape of a forged iron cross-shaped pendant made by joining two flat and thin rods. A suspension loop for hanging by a string or chain, made by folding back the top of the iron rod, is present on the upper arm of the cross, which is longer than the others.

\section{SA-2005-AK-14-42 (Figure 5(b))}

This forged iron cross-shaped pendant (32 $\mathrm{mm}$ long and $20 \mathrm{~mm}$ wide) was found in burial no. 2 of 2005 (SA-2005-AK-II: locus 16 of sector 2290/2365) to the south of the church. This pit burial contained the skeleton of an infant between one and two years of age (SA-2005-AK-38). The body was interred in supine position with the legs stretched and the arms folded on the chest. This child was oriented eastwest with the head at the west end of the grave. The pit $(0.77 \mathrm{~m}$ long, $0.26 \mathrm{~m}$ wide, and $0.18 \mathrm{~m}$ deep) had a lining of limestone rubble. In addition to the iron cross-shaped pendant around its neck, the child wore a cobalt blue glass bracelet around its right wrist (SA-2005-AK-40) and a copper-alloy ring on one of its left fingers (SA-2005-AK-42); furthermore, a copper-alloy earring in the form of a simple hoop with a hook and loop fastening (SA-2005-AK-42) was found. The presence of a glass bracelet may identify the infant as a girl, as such bracelets were generally worn by female individuals (Lauwers et al., 2010: 150). The ceramic material of the grave fill provided a terminus post quem in the Middle Byzantine period (eleventh-thirteenth century $\mathrm{AD}$ ). This is confirmed by the glass bracelet, which can be dated between the tenth and thirteenth century $\mathrm{AD}$ (Lauwers et al., 2010), and a radiocarbon date between 1170 and $1285 \mathrm{cal} \mathrm{AD} \mathrm{(at} 2 \sigma$ or 95.4 per cent probability).

Two similar forged iron cross pendants were found at Zeytinli Bahçe in a secondary burial (no. 28) dated to the twelfththirteenth century (Dell'Era, 2012: 404 fig. 12e-f and 405).

\section{Type 2}

Type 2 comprises copper-alloy crosses cast in moulds, with arms ending in roundels in the shape of dotted circles.

\section{Type 2a}

This subtype consists of four arms, two shorter horizontal and two longer vertical ones. The edges of the arms are indicated by fluting. The arms end in roundels in the shape of dotted circles which imitate inlaid decoration. Such a roundel is also present at the centre of the cross. A suspension loop for hanging on a string or chain is present on the top of the upper roundel.

SA-1999-LA-18.2 (Figure 5(c))

This copper-alloy cross-shaped pendant (33 $\mathrm{mm}$ long and $25 \mathrm{~mm}$ wide) was found on the Lower Agora, in burial no. 2 excavated in 1999 (SA-1999-LA-II). This grave has already been described (see Type 1a). As mentioned, it was found together with an iron pectoral cross of Type 1a 
(SA-1999-LA-18.3) and a copper-alloy cross of Type 5 (SA-1999-LA-18.1).

\section{SA-1996-LA-46 (Figure 5(d))}

This copper-alloy cross-shaped pendant (33 $\mathrm{mm}$ long and $25 \mathrm{~mm}$ wide) was found on the Lower Agora (sector 2320/2365, layer 2) in burial no. 2, the grave of a child (aged one and a half to two years) excavated in 1996 (grave SA-1996-LAII). This child was buried in a supine position with legs stretched out. The individual was oriented east-west, with the head at the west end of the grave, facing east. The grave was lined with irregular limestone blocks. Besides the cross described here, another pendant of Type 4a (SA1996-LA-47) was found. Both were found on top of the upper left ribs and the left clavicle, causing a green discoloration of the bone. A small copper-alloy ring ( $6 \mathrm{~mm}$ in diameter), found underneath the skull, probably served as an element of the string on which the cross used to hang. The radiocarbon date of the skeleton could be calibrated to $1025-1168 \mathrm{cal} \mathrm{AD}$ (at $2 \sigma$ or 95.4 per cent probability).

Similar crosses have been found in cemeteries in Thessaloniki, which were dated to the mid-thirteenth to midfifteenth century AD (Antonaras, 2012: 123 and fig. 10), and three identical crosses were found in the burial of a child (no. 133) at Herakleia Perinthos, dated to the ninth-twelfth century AD (Westphalen, 2012: 132 fig. 5, 133 fig. 6 and 134).

\section{Type $2 b$}

This subtype represents a copper-alloy clover-shaped pendant cast in a mould, consisting of four roundels in the shape of dotted circles forming a cross around a central circular pellet. A suspension loop is present on top of the upper disk.

\section{SA-1995- $A G$-301 (Figure 5(e))}

This cross (21 mm long and $16 \mathrm{~mm}$ wide) was found in burial no. 3 at Agora Gate (SA-1995-AG-III: sector 2325/2345, layer 4), excavated in 1995 . The grave yielded the remains of a child (c. two years old) and a woman (aged twenty-one to twentythree years). The remains of the woman were disturbed, but still articulated. The individual was interred in a supine position, with the legs stretched and the arms positioned next to the body. She was oriented east-west, with head towards the west. The skeleton of the child was less well preserved: the remains were reduced and very disturbed. This makes it impossible to associate the cross directly with either of the skeletons. The grave pit, measuring $1.80 \times 0.65 \mathrm{~m}$, was covered and lined with stone rubble. The pottery found within the fill of the burial provided a Middle Byzantine terminus post quem for this grave. The adult individual was radiocarbon-dated between 1185 and 1290 cal AD (at $2 \sigma$ or 95.4 per cent probability).

\section{Type 3}

Type 3 comprises copper-alloy crossshaped pendants cast in moulds, consisting of four flaring arms, two shorter horizontal and two longer vertical ones. The arms of the cross terminate in roundels with two small teardrops on either side of them. A suspension loop is present on top of the upper arm.

\section{$S A-1995-A G-250$ (Figure 5(h))}

Within each of the roundels of this crossshaped pendant $(31 \mathrm{~mm}$ long and $23 \mathrm{~mm}$ wide) remains of yellow enamel were present. The intersection of the arms was hollowed, probably indicating the presence of a glass (or enamel) inlay which is now missing. The back of the cross is flat and 
without ornamentation. It was found in burial no. 2, located on top of the Agora Gate staircase and excavated in 1995 (SA1995-AG-II: sector 2325/2345, layer 4). Within this grave, measuring $0.40 \times 0.80 \mathrm{~m}$, the remains of a two to three year old child were unearthed. This child was oriented east-west, its head towards the west, in a supine position with the legs stretched and the arms folded on the abdomen. The grave itself was a simple pit. The cross was found on the chest of the child.

\section{SA-1995-AG-323 (Figure 5(j))}

The lower arm of this copper-alloy pendant (30 mm long and $20 \mathrm{~mm}$ wide) is longer than the others. A small cross is incised in each of the roundels at the end of the arms. The intersection of the arms is hollowed out, probably for the inset of glass paste, now lost. The back of the cross is flat and without ornamentation. The cross was found in burial no. 7, excavated in 1995 on top of the Agora Gate staircase (SA-1995-AG-VII: sector 5330/ 4765, layer 4). Within this burial, the remains of a child (aged one to two years) were unearthed. The reduced remains were scattered over the grave, but it was still possible to ascertain that the grave was oriented east-west with the head at the west end. The cross was found on the body of the deceased. The burial pit, measuring $0.80 \times 0.60 \mathrm{~m}$, was lined with rubble stones, while its floor was paved with tiles and bricks. The most recent pottery from its fill could be dated between the seventh and tenth centuries $\mathrm{AD}$, giving us a terminus post quem for this grave.

Crosses with convex semi-circular terminals and small protrusions were common from the eleventh century onwards (Evans \& Wixom, 1997: cat. no. 124). A similar cross was found in the burial of a child (no. 133) at Herakleia Perinthos, dated to the ninth-twelfth centuries $\mathrm{AD}$ (Westphalen, 2012: 132 fig. 5, 133 fig. 6, and 134). Another example of this type was excavated at Saraçhane (Istanbul), in an undated context (Harrison, 1986: 269 no. 625, plate 426).

\section{Type 4}

Type 4 refers to copper-alloy cross-shaped pendants cast in moulds, consisting of a cubic centre with four cone-shaped arms. A suspension loop is present on top of the upper arm.

\section{Type 4a}

This subtype consists of a cubic centre with four identical cone-shaped arms. On the top surface of the cube, a cross is incised diagonally.

\section{SA-1996-LA-47 (Figure 5(f))}

This copper-alloy cross-shaped pendant (34 $\mathrm{mm}$ long and $25 \mathrm{~mm}$ wide) was found in burial no. 2, which was excavated on the Lower Agora in 1996 (grave SA1996-LA-II: sector 2320/2365, layer 2). The grave has already been described in the discussion of a cross of Type 2a (SA1996-LA-46).

A comparable cross was found in the burial of a child (no. 133) at Herakleia Perinthos, dated to the ninth-twelfth century AD (Westphalen, 2012: 132 fig. 5, 133 fig. 6, and 134).

\section{Type 4b}

Subtype $4 \mathrm{~b}$ consists of a cubic centre with four cone-shaped arms, two shorter horizontal and two longer vertical ones. Each 
of the arms ends in two drum-shaped ornaments.

\section{SA-1995-AG-296 (Figure 5(g))}

The copper-alloy cross (28 mm long and $16 \mathrm{~mm}$ wide) was found in burial no. 10 excavated in 1995 on top of the Agora Gate staircase (SA-1995-AG-X: sector $2325 / 2350$, layer 4$)$. This grave of a child (aged one to one and a half years), measuring $1.08 \times 0.73 \mathrm{~m}$, was partly stone-lined on the south side, and some stones also covered it. The skeletal remains were very disturbed, with the whole left arm missing. An east-west orientation with the head at the west end was still observable. The cross was found on the child's chest.

Pectoral crosses similar to this subtype were found at Yumuktepe in Cilicia (Köroğlu, 2004: no. 5) and at Zeytinli Bahçe in Osrhoene (Dell'Era, 2012: 404 fig. $12 \mathrm{~h}$ and 405$)$ in contexts dated to the eleventh-thirteenth and twelfth-thirteenth centuries, respectively.

\section{Type 5}

This type of copper-alloy cross-shaped pendant cast in moulds consists of four arms, two shorter horizontal and two longer vertical ones. Each of the arms has two spherical knobs on its splayed ends and a rib in the middle of the arm. The edges of the arms are indicated by fluting. A suspension loop is present on top of the upper arm.

\section{SA-1999-LA-18.1 (Figure 5(k))}

The copper-alloy cross-shaped pendant (32 $\mathrm{mm}$ long and $20 \mathrm{~mm}$ wide) was recovered in burial no. 2 on the Lower Agora in 1999 (2390/2315, layer 2). This grave has already been discussed since it also contained an iron cross of Type 1 (SA1999-LA-18.3) and a copper-alloy cross of Type 2a (SA-1999-LA-18.2). The Type 5 and Type 1a crosses were joined by corrosion, suggesting that they were placed closely together during burial, probably originally as part of the same necklace.

A similar pectoral cross was found in a burial at the Middle Byzantine graveyard in the village of Boğazköy which was allegedly abandoned in the second half of the eleventh century due to the Seljuk invasion (Böhlendorf-Arslan, 2012: 365 fig. 13.20). A comparable cross was also present in the burial of a child (no. 133) at Herakleia Perinthos, dated to the ninthtwelfth centuries AD (Westphalen, 2012: 132 fig. 5, 133 fig. 6, and 134).

\section{Chronology of the Crosses}

The pectoral crosses from Sagalassos can all be firmly placed in the eleventh to thirteenth centuries on the basis of the radiocarbon dates available for some of the burials and the typological parallels with examples from other excavated sites, from Thrace in the west to Osrhoene in the east. These parallels indicate that the typology was common to a large network of workshops scattered throughout the Byzantine Empire.

As Table 1 shows, the three graves with crosses for which radiocarbon dates are available all fall within the elevenththirteenth centuries.

Within both graves SA-1996-LA-II and grave SA-1995-AG-III, a cross of Type 2 was found. Yet, the radiocarbon dates of the associated human remains do not overlap. It, therefore, seems that the clover-shaped subtype $2 \mathrm{~b}$ from grave SA1995-AG-III is more recent than subtype 2a from SA-1996-LA-II. While Type 2a can be attributed to the eleventh-twelfth centuries, Type $2 \mathrm{~b}$ belongs to the late twelfth-thirteenth century. The former 
Table 1. Radiocarbon dates of the skeletal remains associated with crosses.

\begin{tabular}{lccccc}
\hline Grave & Sample & Radiocarbon date & $\mathbf{1 \sigma}$-date (68.2 \%) & 2 $\boldsymbol{\sigma}$-date (95.4 \%) & Cross \\
\hline SA-2005-AK-II & Beta-236225 & $780 \pm 40 \mathrm{BP}$ & $1223-1271 \mathrm{cal} \mathrm{AD}$ & $1170-1285 \mathrm{cal} \mathrm{AD}$ & $1 \mathrm{~b}$ \\
SA-1995-AG-III & Beta-236226 & $770 \pm 40 \mathrm{BP}$ & $1224-1276 \mathrm{cal} \mathrm{AD}$ & $1185-1290 \mathrm{cal} \mathrm{AD}$ & $2 \mathrm{~b}$ \\
SA-1996-LA-II & RICH-22608 & $928 \pm 31 \mathrm{BP}$ & $1043-1154 \mathrm{cal} \mathrm{AD}$ & $1025-1168 \mathrm{cal} \mathrm{AD}$ & $2 \mathrm{a}$ \\
& & & & & $4 \mathrm{a}$ \\
\hline
\end{tabular}

date contradicts a proposed late Byzantine date (thirteenth-fifteenth century $\mathrm{AD}$ ) for Type 2a at Thessaloniki (Antonaras, 2012), but corresponds to the (broad) date at Herakleia Perinthos. Given that Type 2a was found together with Type $4 \mathrm{a}$ in SA1996-LA-II, and with Type 1a and Type 5 in SA-1999-LA-II, a similar date for those types is implied.

Since Type $1 \mathrm{a}$ is contemporary with Type $2 \mathrm{a}$ and can be dated to the eleventhtwelfth centuries $\mathrm{AD}$, while Type $1 \mathrm{~b}$, found in SA-2005-AK-II, was dated between the late twelfth and the end of the thirteenth century $\mathrm{AD}$, it is safe to assume that these types also succeeded each other.

The radiocarbon dates also indicate an eleventh-twelfth century origin for Type 4a. For Type $4 b$ no such date is available, nor were there any other objects present in burial SA-1995-AG-X which could provide chronological indications. Yet, parallels from Yumuktepe and Zeytinli Bahçe (see above) suggest a twelfth-thirteenth century date for this type of pectoral cross, which identifies it as a later development.

Finally, the association of the dated Type 2a with Type 5 in SA-1999-LA-II also places the latter in the eleventhtwelfth centuries. Crosses of Type 1a and Type 5 were also found at Boğazköy in the graveyard of a Byzantine settlement laid out around a monastery (BöhlendorfArslan, 2012). The destruction of the settlement during the late eleventh century, associated with the Seljuk invasions of Anatolia, provides a plausible terminus ante quem for the use of the cemetery, and confirms the suggested date of the types mentioned.

Like Type 4b, Type 3, of which the two specimens were found in contexts not dated by ${ }^{14} \mathrm{C}$ and without any other grave goods, could not be dated on the basis of internal criteria. However, the contemporaneity of this type with some of the other pectoral crosses attested at Sagalassos can be deduced from examples from the Middle Byzantine graveyard at Herakleia Perinthos. There, a necropolis was established on top of an abandoned fifthcentury basilica between the ninth and twelfth centuries, and remained in use until the thirteenth-fourteenth century (Westphalen, 2012). One of the burials (no. 133), a simple pit burial of a child broadly dated to between the ninth and twelfth centuries, contained six crosses in total. They were all part of the same chain found around the neck of the individual and were of four different types, all of which are also present at Sagalassos, namely three crosses of Type 2a, together with crosses of Types 4a, 5, and 3 (Westphalen, 2012: 132 fig. 5, 133 fig. 6, and 134). We may therefore conclude that Type 3 can also be placed in the eleventhtwelfth century.

It, thus, seems that Types 1a, 2a, 3, 4a, and 5 were all contemporary and can be dated to the eleventh and twelfth centuries, while Types $1 \mathrm{~b}, 2 \mathrm{~b}$, and $4 \mathrm{~b}$ date to the late twelfth to thirteenth centuries. Nonetheless, no strict chronological sequence 
should be envisaged. The continued use of Type $1 \mathrm{a}$ and the origin of Type $1 \mathrm{~b}$ in the twelfth century is suggested by examples from eastern Anatolia at Zeytinli Bahçe (Osrhoene) in a grave (no. 28) dated to the twelfth-thirteenth century (Dell'Era, 2012); although the nature of the burial, an ossuarium, could mean that the contents of older graves were mixed with new inhumations. The possible overlap of subsequent types indicates that the transition from the one type to the other was not an abrupt process, but rather a slower evolution.

A horizontal stratigraphy can be suggested for the layout of the graveyard on the basis of the nine radiocarbon dates obtained so far. The calibrated dates from the skeletons excavated in the debris on the west side of the Lower Agora and those between the temenos wall and the western terrace wall of the agora seem to be older than the dates obtained for those buried above the Agora Gate staircase. This development is largely corroborated by the proposed date of the pectoral crosses (Figure 2). It, thus, seems that people were originally buried closer to the sanctuary and then gradually areas further removed from it were brought into use. The aspiration of being interred as close as possible to the church was common practice in Byzantine Asia Minor (Ivison, 1993: 66-76). As the burial densities within and outside the temenos wall of the former Apollo Klarios temple are very different, this demarcation was obviously still important in Middle Byzantine times. Within the enclosure, the density was much greater.

\section{Use of The Crosses}

In the discussion of the different types, it becomes clear that the eleven pectoral crosses found at Sagalassos were present in burials of sub-adults, a characteristic which they shared with other types of personal adornment. In Byzantine times, the bodies of children were laid out in much the same way as those of adults, but, unlike adults, they were often adorned with jewellery (Talbot, 2009: 300-01). While, in the Early Byzantine period, jewellery was found in both children's and adults' graves, in Middle Byzantine times it was no longer given to adult individuals (Pitarakis, 2009: 193), and the data from Sagalassos confirm this. Only thirteen of the fifty-eight burials (or 22 per cent) contained objects; and, in all of them, remains of children were found, either in a single or a multiple burial (with an adult or another child).

The shape and size of most items, such as the glass bracelets all having a diameter of $50 \mathrm{~mm}$ or less (Lauwers, 2008), allows them to be identified as miniature pieces, designed for children. Further, finger rings found in graves at Boğazköy were worn by children, as indicated by their small diameter; although glass bracelets there were worn by both children and adults (Böhlendorf-Arslan, 2012: 363-64). The practice of adorning children of both genders with items of jewellery is attested throughout the history of the Byzantine Empire, and parents also took care to ornament their children in death (Pitarakis, 2009: 187-91). At Sagalassos, this is illustrated in particular by burial SA-2005-AK-II where, together with the pectoral cross of Type $1 \mathrm{~b}$, a copper-alloy ring, a glass bracelet, and a copper-alloy earring have been found (see above; Figure 3). Another example at Sagalassos is grave 6, which was excavated west of the western terrace wall of the Lower Agora in 1998. In this grave, a two-yearold child ( \pm eight months) had six glass bracelets on its right arm and one on its left. As the ornaments given to the child were too cumbersome to have been worn on a daily basis, it seems that these glass 
bracelets did not serve as jewellery during life, but were given to the child as grave goods. Similar practices have been observed at the Djadovo necropolis in Bulgaria, where a five to six-year-old was buried with eleven glass and copper-alloy bracelets on its right arm (Fol et al., 1989: 338).

The pendant crosses are the most common ornaments recovered so far, since they account for thirty-seven per cent of all the objects. The prevalence of jewellery in children's burials from the Middle Byzantine period illustrates the perceptions and beliefs about premature death in ancient societies. Crosses were part of the adornment of children, but they were also associated with a desire to protect them. This was perpetuated in funerary rituals in which we see the desire to protect a child on its journey to the realm of the dead (Pitarakis, 2009: 194).

Yet, not all children had a cross pendant. At Sagalassos, they appear to have been typical gifts for small children, since all the crosses that were found accompanied children between one and five years old. Despite their very young age, the fact that the children were given a formal burial amidst the adult members of the community suggests that they had been baptized and were considered part of the local congregation. Only three children younger than one year old have so far been found, suggesting that unbaptized neonates were buried separately, as was the case in Amorium (Ivison, 2010: 338). The prominence of devices like pectoral crosses intended for protecting children is important for understanding the role of children in local society during the Byzantine period. Keeping children healthy was a universal preoccupation that the Sagalassians were deeply concerned with.

Of the seventy-four skeletons studied at Sagalassos, at least forty-six (or 62 per cent) belonged to sub-adults. Of those forty-six, thirty-five were (well) under five years old, not including the unbaptized neonates, illustrating the traditionally high rate of infant mortality in pre-industrial times. In Byzantine society, the death of infants and children was an all-toocommon phenomenon. Recent excavations of Byzantine cemeteries are generating significant new data on sub-adult burial that indicate high death rates (40 to 50 per cent) among infants and children (Talbot, 2009). Children's skeletons represent a substantial percentage of the individuals whose remains have been excavated, even if they are less likely to be preserved and are more difficult to recover.

Earlier studies indicate that the contemporary community at Sagalassos was in poor health (Fuller et al., 2012), which will have contributed to this high death rate among children. Scurvy, iron-deficiency anaemia (indicated by cribra orbitalia) as well as malnutrition (reflected by linear enamel hypoplasia), which would have made children more vulnerable to infectious disease, have been suggested as general causes of high infant and child mortality during this period (Talbot, 2009: 287). At Sagalassos, the evidence also points in this direction: cribra orbitalia has been observed on nine skeletons and two individuals showed linear enamel hypoplasia. 1

Moreover, a further particular cause of death can be suggested, based on the evidence from Sagalassos. Recent isotopic analysis for the detection of breastfeeding and weaning patterns in Greek Byzantine populations has demonstrated that weaning occurred around the ages of two to three (Bourbou, 2004: 67-68; Bourbou \& Garvie-Lok, 2009). This age group sees a high incidence of mortality at Sagalassos, where we have twenty-nine 2-3 year-old

1 The osteological study was carried out by Elisabeth Smits and Katrien Van de Vijver. 
individuals (39 per cent). The death of a major portion of the infants and young children buried in a Middle Byzantine cemetery at Xironomi in Greece has also been related to weaning (Tritsaroli \& Valentin, 2008: 105). During weaning, breast milk was substituted with preparations, including wheat or barley cooked in water as well as goat's milk, sometimes mixed with honey (Jackson, 1989). The infant deaths reveal the dangers of malnutrition and diarrhoea resulting from the shift to a diet of cereal and goat's milk. Weaning was a crucial time in a child's life, and the nutritional value of supplementary foods, as well as sanitary conditions in which feeding took place, were of vital importance. A clear indication of this is that the majority of individuals with cribra orbitalia fall within this age range (six out of nine, or 67 per cent). Therefore, we consider it as no coincidence that pectoral crosses were found especially in this age group, with all individuals with crosses belonging to this subset.

In popular belief, the high incidence of infant mortality was attributed to the evil eye (Dickie, 1995). Pregnant women and young children were thought to be particularly vulnerable to its influence. One of its manifestations was to provoke the action of a female demon, commonly identified as Gello, whose aggression was principally directed against babies and mothers immediately before or after delivery (Pitarakis, 2009: 197). Amulets were often used to protect newly-born children against the demon during the dangerous period between birth and baptism (Talbot, 2009: 291). Gello was believed to pose a danger especially in the first weeks after birth, but the evil eye was a constant threat for small children, who needed the protection of a multiplicity of practices and devices (Pitarakis, 2009: 200). The fight against such demonic activity at Sagalassos is already reflected by a group of sixth-century pendant amulets (Talloen, 2011: 597-99). One side of these amulets bears the image of the Holy Rider, identified as Solomon, attacking the prostrate female demon. On the other side, a clover-shaped cross composed of four roundels is depicted.

Since the Early Byzantine period, the cross was promoted by the Church Fathers as the most powerful agent against evil (Pitarakis, 2009: 202). Consequently, the use of pectoral crosses became commonplace, gradually superseding the use of other types of protective devices. They afforded their wearers protection from evil spirits that constantly threatened all aspects of daily life (Pitarakis, 2009: 202, 2010: 164). The Middle Byzantine cross pendants may, thus, have been used as apotropaic instruments to protect infants from premature death during or after the period of weaning. This would make them a material manifestation of the struggle of parents to keep their infants alive during this most dangerous transition in life. The concern for salvation meant that the crosses also accompanied their recipients to their graves (Pitarakis, 2010: 173).

Yet, only nine of the twenty-nine two/ three-year-olds (or 31 per cent) received a cross. Another criterion, perhaps gender, may, therefore, have been influential. At other Middle Byzantine sites, the bulk of the jewellery was found in the burials of little girls (e.g. Laskaris, 2000: 248; Pitarakis, 2009: 202). This perhaps reflected the custom of 'marriage to death', the perception of death as a marriage to the underworld deities, especially in the case of a young unmarried person (Pitarakis, 2009: 194). It is, however, extremely difficult to determine the sex of the skeletal remains of a sub-adult (Baker et al., 2005: 10). The analysis of the aDNA of some skeletons from the Sagalassos graveyard indicated a female sex for one of the children between two and three years old (Jehaes et al., 2000: 
829). This girl, however, was not given any grave goods, be it jewellery or cross. It, therefore, is not possible to say anything of the gender-association of the crosses at the present time.

\section{Conclusion}

The aim of this paper is to present the different types of pendant crosses found in the burials of a Middle Byzantine graveyard at the Pisidian settlement of Sagalassos, and the light they shed on funerary practices in this part of the Byzantine world. In general, the crosses could be dated to between the eleventh and thirteenth centuries $\mathrm{AD}$, providing an indication for the lifespan of the cemetery. Moreover, the typological evolution, which was corroborated by parallels from other sites in the Byzantine Empire, suggesting a supra-local applicability, makes it possible to construct a horizontal stratigraphy for the graveyard. The pectoral crosses discussed here proved to belong in most cases to very young children between two and three years old, a period during which they were weaned. These crosses constitute a category of material culture that not only provides insights into the lives of the Byzantine population, especially during the period of early childhood, but are also the material manifestation of the intersection of popular religion, magic, and funerary rites. They reflect Byzantine parents' profound concerns with the health and well-being of their offspring, and illustrate how they resorted to such apotropaic instruments to protect their infants, in life and death.

\section{ACKNOWLEDGEMENTS}

The authors are members of the Sagalassos Archaeological Research Project. From 1990 to 2013, the fieldwork activities and research programme were directed by Marc Waelkens and from 2014 onwards by Jeroen Poblome (both University of Leuven, Belgium). This research was supported by the Belgian Programme on Interuniversity Poles of Attraction, the Research Fund of the University of Leuven, and the Research FoundationFlanders (FWO). We would like to thank the Ministry of Culture and Tourism of the Republic of Turkey, its General Directorate of Culture and Museums (Kültür Varlıkları ve Müzeler Genel Müdürlüğ̈̈), and its representatives for permission to excavate, for support, and much-appreciated help during the fieldwork campaigns.

\section{REFERENCES}

Antonaras, A.C. 2012. Middle and Late Byzantine Jewellery from Thessaloniki and its Region. In: B. Böhlendorf-Arslan \& A. Ricci, eds. Byzantine Small Finds in Archaeological Contexts (Byzas 15). Istanbul: Ege Yayınları, pp. 117-26.

Baker, B.J., Dupras, T.L. \& Tocheri, M.W. 2005. The Osteology of Infants and Children. College Station (TX): Texas A\&M University Press.

Böhlendorf-Arslan, B. 2012. Das bewegliche Inventar eines mittelbyzantinischen Dorfes: Kleinfunde aus Boğazköy. In: B. Böhlendorf-Arslan \& A. Ricci, eds. Byzantine Small Finds in Archaeological Contexts (Byzas 15). Istanbul: Ege Yayınlar1, pp. 351-68.

Bourbou, C. 2004. The People of Early Byzantine Eleutherna and Messene (6th-7th Centuries AD): A Bioarchaeological Approach. Athens: University of Crete.

Bourbou, C. \& Garvie-Lok, S.J. 2009. Breastfeeding and Weaning Patterns in Byzantine Times: Evidence from Human Remains and Written Sources. In: A. Papaconstantinou \& A.-M. Talbot, eds. Becoming Byzantine: Children and Childhood in Byzantium. Washington (DC): Dumbarton Oaks Research Library 
and Collection, Harvard University Press, pp. 65-83.

Bronk Ramsey, C. 2009. Bayesian Analysis of Radiocarbon Dates. Radiocarbon, 51: 337-60.

Cleymans, S. \& Poblome, J. forthcoming. The Funerary Landscape of the Middle Byzantine Graveyard. In: Kazı Sonuçlar Toplantısı 39. Ankara: Ministry of Culture.

Constas, N. 2010. Death and Dying in Byzantium. In: D. Krueger, ed. Byzantine Christianity (A People's History of Christianity 3). Minneapolis: Fortress Press, pp. 124-45.

Davies, J. 1999. Death, Burial, and Rebirth in the Religions of Antiquity. New York: Routledge.

Dell'Era, F. 2012. Small Finds from Zeytinli Bahçe-Birecik (Urfa). In: B. BöhlendorfArslan \& A. Ricci, eds. Byzantine Small Finds in Archaeological Contexts (Byzas 15). Istanbul: Ege Yayınları, pp. 393-406.

Dickie, M.W. 1995. The Fathers of the Church and Evil Eye. In: H. Maguire, ed. Byzantine Magic. Washington: Harvard University Press, pp. 9-34.

Evans, H.C. \& Wixom, W.D. 1997. The Glory of Byzantium: Art and Culture of the Middle Byzantine Era AD 843-1261. New York: The Metropolitan Museum of Art.

Fol, A., Katinčarov, R., Best, J., de Vries, N., Shoju, K. \& Suzuki, H. 1989. Djadovo: Bulgarian, Dutch, Japanese Expedition: Mediaeval Settlement and Necropolis (11th12th Century) (Vol. 1). Tokyo: Tokai University Press.

Fuller, B.T., De Cupere, B., Marinova, E., Van Neer, W., Waelkens, M. \& Richards, M. P. 2012. Isotopic Reconstruction of Human Diet and Animal Husbandry Practices during the Classical, Hellenistic, Imperial, and Byzantine Periods at Sagalassos, Turkey. American Journal of Physical Anthropology, 149: 157-71.

Harrison, R.M. 1986. Excavations at Saraçhane in Istanbul: The Excavations, Structures, Architectural Decoration (Vol. 1). Princeton (NJ): Princeton University Press.

Ivison, E.A. 1993. Mortuary Practices in Byzantium (c. 950-1453). An Archaeological Contribution (unpublished $\mathrm{PhD}$ dissertation, University of Birmingham).

Ivison, E.A. 2010. Kirche und religiöses Leben im byzantinischen Amorium. In:
F. Daim \& J. Drauschke, eds. Byzanz Das Römerreich im Mittelalter, II. Mainz: Schnell \& Steiner, pp. 309-43.

Jackson, R. 1989. Doctors and Diseases in the Roman Empire. London: The British Museum.

Jehaes, E., Waelkens, M., Muyldermans, A., Cassiman, J.-J., Smits, E., Poblome, J. et al. 2000. DNA Analysis of the Archaeological Human Remains from Sagalassos. In: M. Waelkens \& L. Loots, eds. Sagalassos V. Report on the Survey and Excavation Campaigns of 1996 and 1997. Leuven: Leuven University Press, pp. 821-31.

Khairedinova, E.A. 2012. Early Medieval Crosses from the South-Western Crimea. In: B. Böhlendorf-Arslan \& A. Ricci, eds. Byzantine Small Finds in Archaeological Contexts (Byzas 15). Istanbul: Ege Yayınları, pp. 417-40.

Köroğlu, G. 2004. Yumuktepe in the Middle Ages. In: I. Caneva \& V. Sevin, eds. Mersin-Yumuktepe: A Reappraisal. Lecce: Congedo, pp. 103-32.

Laskaris, N.G. 2000. Monuments funéraires paléochrétiens (et byzantins) de Grèce. Athènes: Editions Historiques Stéfanos D. Basilopoulos.

Lauwers, V. 2008. The Glass of Sagalassos. Towards a Geochemical and Typochronological Interpretation (unpublished $\mathrm{PhD}$ dissertation, University of Leuven).

Lauwers, V., Degryse, P. \& Waelkens, M. 2010. Middle Byzantine (10th-13th Century AD) Glass Bracelets at Sagalassos (SW Turkey). In: J. Drauschke \& D. Keller, eds. Glass in Byzantium: Production, Usage, Analyses. International Workshop organised by the Byzantine Archaeology Mainz, 17th-18th of January 2008. Mainz: Verlag des RömischGermanisches Zentralmuseum, pp. 145-52.

Moore, S.V. 2013. A Relational Approach to Mortuary Practices within Medieval Byzantine Anatolia (unpublished $\mathrm{PhD}$ dissertation, University of Newcastle).

Pitarakis, B. 2006. Les croix-reliquaires pectorales byzantines en bronze. Paris: Bibliothèque des Cahiers Archéologiques.

Pitarakis, B. 2009. The Material Culture of Childhood in Byzantium. In: A. Papaconstantinou \& A.-M. Talbot, eds. Becoming Byzantine: Children and Childhood in Byzantium. Washington 
(DC): Dumbarton Oaks Research Library and Collection, Harvard University Press, pp. 167-250.

Pitarakis, B. 2010. Objects of Devotion and Protection. In: D. Krueger, ed. Byzantine Christianity (A People's History of Christianity 3). Minneapolis: Fortress Press, pp. 164-81.

Poblome, J., Talloen, P. \& Kaptijn, E. 2017. Byzantine Sagalassos. In: P. Niewöhner, ed. The Archaeology of Byzantine Anatolia: From Late Antiquity to the Coming of the Turks. Leiden: Brill.

Reimer, P.J., Bard, E., Bayliss, A., Beck, J.W., Blackwell, P.G., Bronk Ramsey, C., et al. 2013. IntCal13 and Marine13 Radiocarbon Age Calibration Curves 0-50,000 years cal BP. Radiocarbon, 55: 1869-87.

Ricaut, F.X. \& Waelkens, M. 2008. Cranial Discrete Traits in a Byzantine Population and Eastern Mediterranean Population Movements. Human Biology, 80: 535-64.

Schoolman, E.M. 2010. Kreuze und kreuzförmige Darstellungen in der Alltagskultur von Amorium. In: F. Daim \& J. Drauschke, eds. Byzanz - Das Römerreich im Mittelalter, II. Mainz: Schnell \& Steinter, pp. 373-86.

Talbot, A.-M. 2009. The Death and Commemoration of Byzantine Children. In: A. Papaconstantinou \& A.-M. Talbot, eds. Becoming Byzantine: Children and Childhood in Byzantium. Washington (DC): Dumbarton Oaks Research Library and Collection, Harvard University Press, pp. 283-308.

Talloen, P. 2007. Test Soundings in the Sanctuary of Apollo Klarios. In: 28. Kazı Sonuçları Toplantısı, 2. Ankara: Ministry of Culture, pp. 327-30.

Talloen, P. 2011. From Pagan to Christian: Religious Iconography in Material Culture from Sagalassos. In: L. Lavan \& M. Mulryan, eds. The Archaeology of Late Antique Paganism (Late Antique Archaeology 7). Leiden: Brill, pp. 575-607.

Talloen, P. \& Poblome, J. 2014. PQ 4'te gerçekleştirilen Kazı Çalışmaları. In: 35. Kazı Sonuçları Toplantısı, 2. Ankara: Ministry of Culture, pp. 250-51.

Talloen, P. \& Vercauteren, L. 2011. The Fate of Temples in Late Antique Anatolia. In: L. Lavan \& M. Mulryan, eds. The Archaeology of Late Antique Paganism (Late
Antique Archaeology 7). Leiden: Brill, pp. 347-87.

Tritsaroli, P. \& Valentin, F. 2008. Byzantine Burial Practices for Children: Case Studies Based on a Bioarchaeological Approach to Cemeteries from Greece. In: F. Gusi Jener, S. Muriel \& C. Olària, eds. Nasciturus, infans, puerulus vobis mater terra: la muerte en la infancia. Castelló: Disputación Provincial de Castelló, pp. 93-113.

Waelkens, M., Vermeersch, P.-M., Paulissen, E., Owens, E.J., Arıkan, B., Martens, M., et al. 1997. The 1994 and 1995 Excavation Seasons at Sagalassos. In: M. Waelkens \& J. Poblome, eds. Sagalassos IV: Report on the Survey and Excavation Campaigns of 1994 and 1995 (Acta Archaeologicae Lovaniensia Monographiae 9). Leuven: Leuven University Press, pp. 103-216.

Waelkens, M., Poblome, J., Paulissen, E., Talloen, P., Van Den Bergh, J., Vanderginst, V., et al. 2000. The 1996 and 1997 Excavation Seasons at Sagalassos. In: M. Waelkens and L. Loots, eds. Sagalassos V: Report on the Survey and Excavation Campaigns of 1996 and 1997 (Acta Archaeologica Lovaniensia Monographiae 11A). Leuven: Leuven University Press: 217-398.

Westphalen, S. 2012. Kleinfunde aus der Basilikagrabung am Kalekapi in Marmara Ereğlisi (Herakleia Perinthos). In: B. Böhlendorf-Arslan \& A. Ricci, eds. Byzantine Small Finds in Archaeological Contexts (Byzas 15). Istanbul: Ege Yayınları, pp. 127-35.

\section{BiographicAl Notes}

Sam Cleymans is a $\mathrm{PhD}$ student working on the population history, health, and quality of life of the different chronological populations at Sagalassos. He is a member of the Sagalassos Archaeological Research Project (SARP; University of Leuven).

Address: Sagalassos Archaeological Research Project, University of Leuven, Blijde Inkomststraat 21, PO box 3314, 3000 
Leuven, Belgium. [email: sam.cleymans@ kuleuven.be]

Peter Talloen is a postdoctoral researcher at the University of Leuven. His doctoral and postdoctoral research focused on religious practices in the ancient region of Pisidia (SW Turkey) from the early Hellenistic to the Early Byzantine period.
Currently, he is studying the urbanization process at the city of Sagalassos, and the role of ideology and communal identity in this process.

Address: Sagalassos Archaeological Research Project, University of Leuven, Blijde Inkomststraat 21, PO box 3314, 3000 Leuven, Belgium. [email: peter.talloen@ kuleuven.be]

\section{Protéger les vivants et les morts: les pendentifs à croix de la nécropole d'Apollon Clarios à Sagalassos}

Dans cet article nous présentons les différents types de pendentifs à croix retrouvés dans les sépultures d'une nécropole de l'époque byzantine moyenne dans la ville de Sagalassos en Pisidie (sud-ouest de la Turquie). Notre étude concerne la chronologie et l'usage de ces pendentifs. Nous nous basons sur diverses sources, allant des données stratigraphiques aux datations radiocarbone, et des informations sur le contexte aux résultats de l'analyse des ossements humains. En général les pendentifs à croix datent du XIe au XIIIe siècle apr. J.-C., ce qui nous donne une idée de la durée d'occupation de la nécropole. De plus, l'évolution typologique, corroborée par des exemplaires provenant d'autres sites de l'empire byzantin, nous a permis d'ébaucher une stratigraphie horizontale de la nécropole. Les pendentifs à croix présentés ici nous éclairent sur les pratiques funéraires de cette partie du monde byzantin. En général ils appartenaient à de très jeunes enfants et représentent une catégorie de la culture matérielle qui nous renseigne non seulement sur la vie de la population byzantine (et surtout sur la petite enfance) mais encore sur les croisements entre la religion populaire, la magie et les rites funéraires. Translation by Madeleine Hummler

Mots clés: pendentifs à croix, Sagalassos, époque byzantine moyenne, pratiques funéraires, enfants

\section{Schutz im Leben und Tod: die Kreuzanhänger aus dem Gräberfeld von Apollo Klarios in Salagassos}

Dieser Artikel betrifft die verschiedenen Typen von Kreuzanbänger, die in den Gräber des mittelbyzantinischen Gräberfeldes von Sagalassos in Pisidien im Südwesten der Türkei gefunden worden sind. Dabei versuchen wir, die Chronologie und auch die Funktion dieser Anbänger zu erleuchten. Wir haben mehrere Quellen untersucht, die von der stratigrafischen Abfolge bis zu Radiokarbondatierungen gehen, und von kontextuellen Angaben bis zur Untersuchung von den menschlichen Überresten. Die Kreuzanhänger werden generell zwischen dem 11. und dem 13. Jh. n.Chr. datiert, was auf die Belegungsdauer des Gräberfeldes binweist. Darüber binaus war es möglich, die typologische Entwicklung, die von Vergleichen mit anderen Funden im byzantinischen Reich bestätigt ist, eine horizontale Stratigrafie des Gräberfeldes aufzustellen. Die hier behandelten Kreuzanhänger liefern wertvolle Angaben über die Grabsitten in diesem Teil des byzantinischen Reiches. Sie wurden meistens in den Gräbern von sebr jungen Kindern gefunden. Diese Gegenstände gehören einer Kategorie von Material, die nicht nur Aufschlüsse über das Leben der byzantinischen Bevölkerung (besonders der Kleinkinder) gibt, sondern auch über die materielle Erscheinungsform der Wechselbeziehungen zwischen Volksreligion, Magie und Grabsitten. Translation by Madeleine Hummler

Stichworte: Kreuzanhänger, Sagalassos, mittelbyzantinisches Reich, Grabsitten, Kinder 